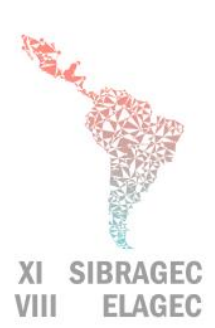

XI SIMPÓSIO BRASILEIRO DE GESTÃO E ECONOMIA DA CONSTRUÇÃO

\section{ENCUENTRO LATINOAMERICANO DE GESTIÓN Y ECONOMÍA DE LA CONSTRUCCIÓN}

Del conocimiento a la acción: prácticas avanzadas de gestión de la producción

Londrina, Paraná, Brasil. 23 al 25 de Octubre del 2019

\title{
LEAN Y CONSTRUCCION SOSTENIBLE: UNA APROXIMACIÓN AL BIENESTAR LABORAL DEL TRABAJADOR DE CONSTRUCCIÓN
}

\section{CARVAJAL-ARANGO, David (1); VASQUEZ-HERNANDEZ, Alejandro (2); BOTERO BOTERO, Luis Fernando (3).}

(1) Universidad EAFIT, (57 4) 261 9500, dcarvaj6@eafit.edu.co (2) Universidad EAFIT, (57 4) 261 9500, extensión 9455, avasqu12@eafit.edu.co, (3) Universidad EAFIT, (57 4) 261 9500, extensión 9659, lfbotero@eafit.edu.co.

\begin{abstract}
Sustainability considers a balance between the economic, social, and environmental dimensions, otherwise known as the triple bottom line. The economic and environmental dimensions have been widely studied, however, the social dimension, which is related to the workplace wellbeing of construction workers, has not been sufficiently addressed. Lean and Sustainable Construction philosophies have proven to be useful in reducing environmental, economic and social impacts of construction projects. For this reason, the objective of this study is to search within these philosophies, aspects and criteria aimed at increasing the wellbeing of construction worker.
\end{abstract}

Keywords: Sustainable Construction, Lean Construction, workplace wellbeing.

\section{INTRODUCCIÓN}

La industria de la construcción se ha caracterizado por las precarias condiciones de bienestar de sus trabajadores. En muchos países, los trabajadores de construcción tienden a presentar mayor vulnerabilidad económica y social que los trabajadores de otras industrias (WATTERSON, 2007). Deben adaptarse a condiciones de bienestar en el trabajo caracterizadas por jornadas laborales extensas (BRADLEY et al., 2007; LINGARD; TURNER, 2017; NIKOLIN et al., 2015), de gran intensidad física (ZHAO, 2014) e inadecuadas condiciones de salud y seguridad, que traen consigo enfermedades físicas y mentales (ULUBEYLI; KAZAZ; ER, 2014; WATTERSON, 2007; ZHAO, 2014), incidentes y accidentes en el sitio de trabajo (DĖJUS; ANTUCHEVIČIENÉ, 2013; ULUBEYLI; KAZAZ; ER, 2014; ZHAO, 2014) e incluso la muerte (JAAFAR et al., 2017; MOHSENI et al., 2015). Además están sujetos a sitios de trabajo poco higiénicos (MOHSENI et al., 2015), aislamiento físico y social (WATTERSON, 2007), exposición a condiciones climáticas cambiantes (ROZENFELD et al., 2010) y dietas inadecuadas (LINGARD; TURNER, 2017). Condiciones que algunos autores relacionan con aumento de propensión a adicciones a drogas y alcohol (JAAFAR et al., 2017; WATTERSON, 2007). Desde las filosofías Lean y Construcción Sostenible se ha buscado el mejoramiento de los procesos de construcción a través de la disminución de 
perdidas, lo cual en la primera de ellas se asocia al aumento de la eficiencia y en la segunda a la disminución de impactos ambientales, económicos y sociales (BAJJOU et al., 2017; DE CARVALHO; GRANJA; DA SILVA, 2017; OGUNBIYI; OLADAPO; GOULDING, 2014; WEINHEIMER; SCHMALZ; MÜLLER, 2017). Sin embargo, la dimensión social, que está relacionada con el bienestar de los trabajadores, no ha sido suficientemente abordada. Por tal razón, el presente trabajo pretende hacer un recorrido por las filosofías Lean y Construcción Sostenible, buscando aspectos y criterios encaminados al aumento del bienestar laboral de los trabajadores de construcción.

\section{MÉTODO DE INVESTIGACIÓN}

Este estudio es de carácter exploratorio y está basado en un análisis de la literatura publicada. A partir de fuentes de información secundarias se pretende identificar variables de bienestar laboral dentro de las filosofías Lean y Construcción Sostenible. Estas variables serán de tipo cualitativo y servirán como punto de partida para un análisis más profundo en futuros estudios.

\section{BIENESTAR LABORAL}

Para algunos autores, el bienestar en su forma más amplia está relacionado con el placer, la felicidad y la minimización del dolor (BRAMBLE, 2016; RYAN; DECI, 2001) y lo entienden como una evaluación personal de todos los aspectos positivos y negativos de la vida (COLE et al., 1999; COSTA; MCCRAE, 1980; DIENER, 2000; DIENER; RYAN, 2009; DIENER; SUH, 1997; JOSEP M et al., 2010; POLLARD; LEE, 2003). Por el contrario, algunos autores afirman que, aunque se genere placer al satisfacer un deseo, no necesariamente se genera bienestar (RYAN; DECI, 2001) y, por tal razón, el bienestar debería centrarse en la autorrealización, el crecimiento, el significado y en el grado en que una persona funciona plenamente (DODGE et al., 2012; RYFF, 1989, 1995; RYFF; SINGER, 2008; SELIGMAN, 2012). El bienestar entendido a partir de la interacción continua entre las personas y su entorno de trabajo se conoce como bienestar laboral (SEGURADO TORRES; AGULLÓ, 2002). El bienestar laboral ha sido estudiado mayormente desde las áreas de la psicología y la sociología (ver Figura-1).

\subsection{Bienestar laboral del trabajador de construcción}

El bienestar laboral en construcción ha sido relacionado con la satisfacción laboral de los trabajadores (SANG; ISON; DAINTY, 2009; SHAN et al., 2016), el desempeño (ABREY; SMALLWOOD, 2014; BRADLEY et al., 2007; GATTI et al., 2014; NIKOLIN et al., 2015), conciliación entre trabajo y familia (MOSTERT; PEETERS; ROST, 2011; TURNER; MARIANI, 2016), compromiso y motivación (BELL; POWELL; SYKES, 2015; KENNEDY; BREWER, 2012; LORENTE et al., 2014), ergonomía y entorno de trabajo (CHOI, 2012; DAMAJ et al., 2016; EAVES; GYI; GIBB, 2016; LIM et al., 2017) y accidentes y enfermedades ocupacionales (BODNER et al., 2014; JAAFAR et al., 2017; LANGDON; SAWANG, 2017; LINGARD; TURNER, 2017; ZHAO, 2014). 
SIBRAGEC - ELAGEC 2019 - del 23 al 25 de Octubre - LONDRINA - PR

Figura 1. Criterios del bienestar laboral abordados desde la psicología y sociología.

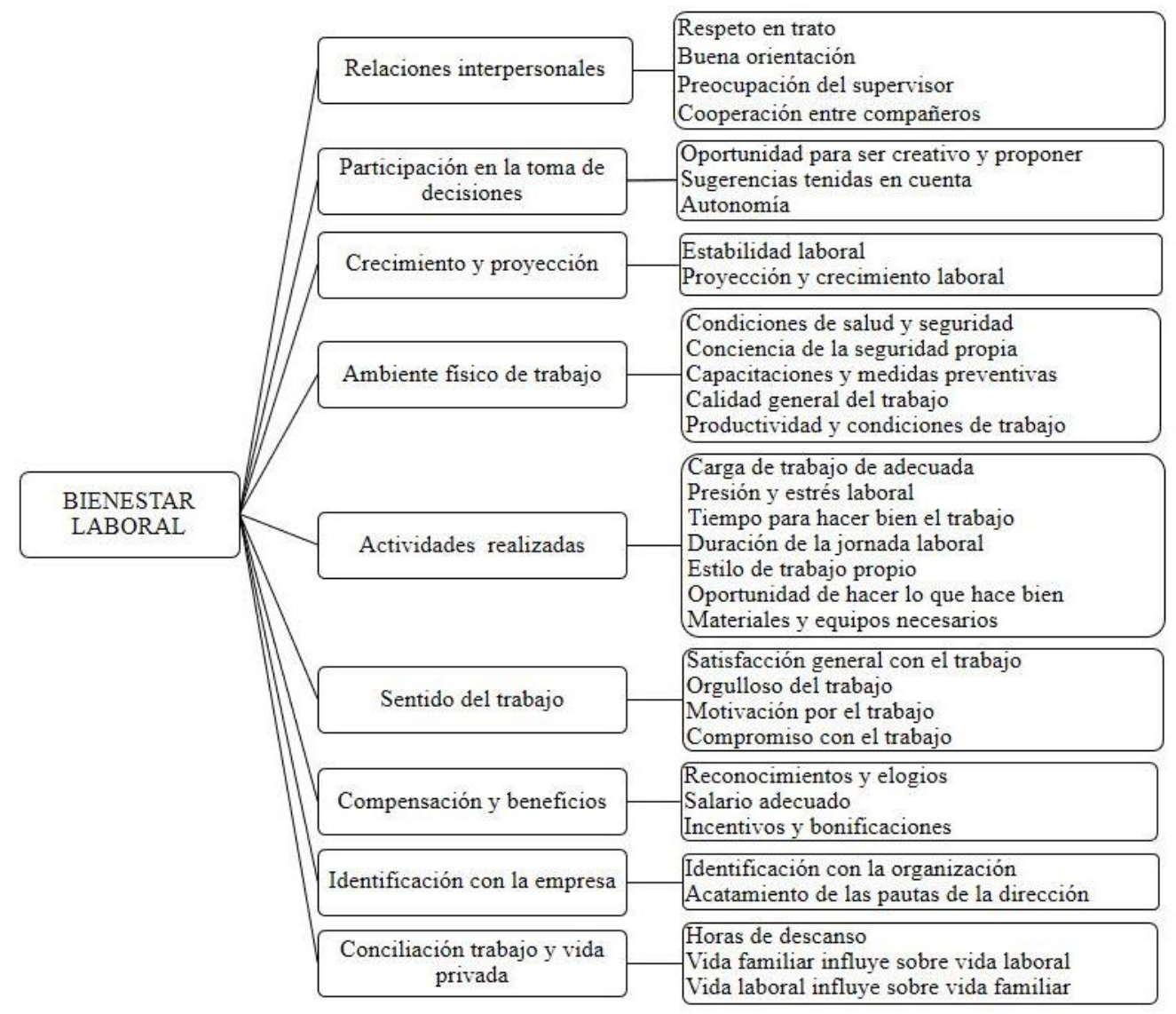

FUENTE: Elaboración propia.

\section{DESARROLLO SOSTENIBLE Y BIENESTAR LABORAL}

La idea de desarrollo está relacionada con la búsqueda del aumento de los niveles bienestar de las personas, a partir de la satisfacción de las necesidades. El modelo de desarrollo occidental está enfocado en el crecimiento económico, el cual, a partir de la revolución industrial, está basado en la extracción de recursos naturales, principalmente litosféricos, que finalmente se transforman en productos consumibles. No obstante, se ha evidenciado que los sistemas naturales de soporte podrían ser un límite que imposibilite suplir la demanda de bienestar exigida por el modelo de desarrollo actual (MEADOWS et al., 1972). Por tal razón, en 1987 se plantea la idea del desarrollo sostenible haciendo alusión al sostenimiento del crecimiento económico en el tiempo, de manera que la satisfacción de necesidades del presente no comprometa la capacidad de satisfacción de necesidades de generaciones futuras (BRUNDTLAND, 1987). Al presente, los esfuerzos encaminados en este sentido se enmarcan en los 17 objetivos del desarrollo sostenible (ONU, 2012), de los cuales, el octavo propende por el "trabajo decente y crecimiento económico", y está centrado en la creación de empleo; derechos laborales, dialogo y protección social (ILO, 2018). 
SIBRAGEC - ELAGEC 2019 - del 23 al 25 de Octubre - LONDRINA - PR

Figura-2. Criterios de bienestar laboral de la OIT

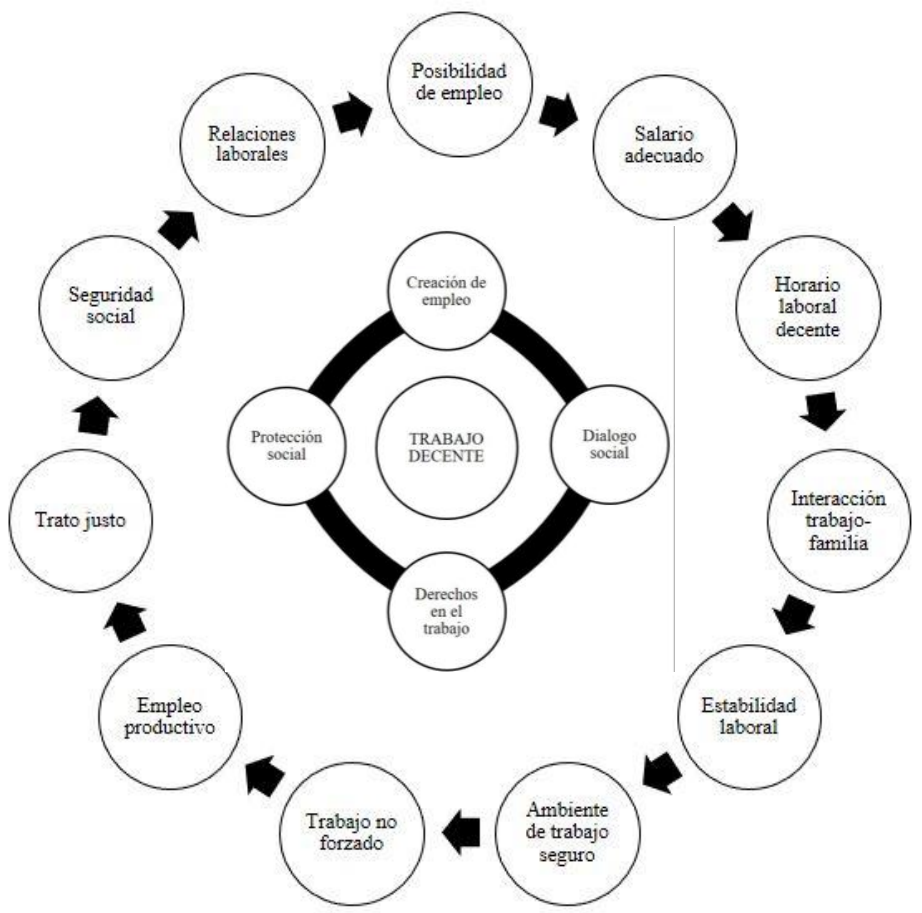

FUENTE: Elaboración propia.

\section{CONSTRUCCIÓN SOSTENIBLE, LEAN-CONSTRUCTION Y BIENESTAR LABORAL}

La Construcción Sostenible tiene como propósito generar bienestar social a partir de: (i) la entrega de productos (i.e. casas, edificios, infraestructura, urbanismo), que afirmen la dignidad, fomenten la equidad y dinamicen la economía, sin alterar el capital natural y, (ii) el ofrecimiento de condiciones de trabajo decente durante los procesos de construcción, para mejorar las condiciones de bienestar de los trabajadores. En la Figura-3 se presentan las fases del ciclo de vida de un proyecto de construcción, como potenciales satisfactores de las necesidades humanas, a partir de las dos posibilidades de generación de bienestar mencionadas anteriormente. Para ello se toma como base las necesidades humanas planteadas por Max Neef (1998). No obstante, la mayoría de los esfuerzos realizados desde la Construcción Sostenible han estado direccionados a la generación de bienestar a partir de la entrega de productos que mejoren las condiciones de vida de las personas durante la fase de uso y mantenimiento, y muy poco se ha hecho por el bienestar de las personas durante los procesos de construcción, es decir, de los trabajadores involucrados. 
SIBRAGEC - ELAGEC 2019 - del 23 al 25 de Octubre - LONDRINA - PR

Figura-3 Construcción como satisfactor de necesidades humanas

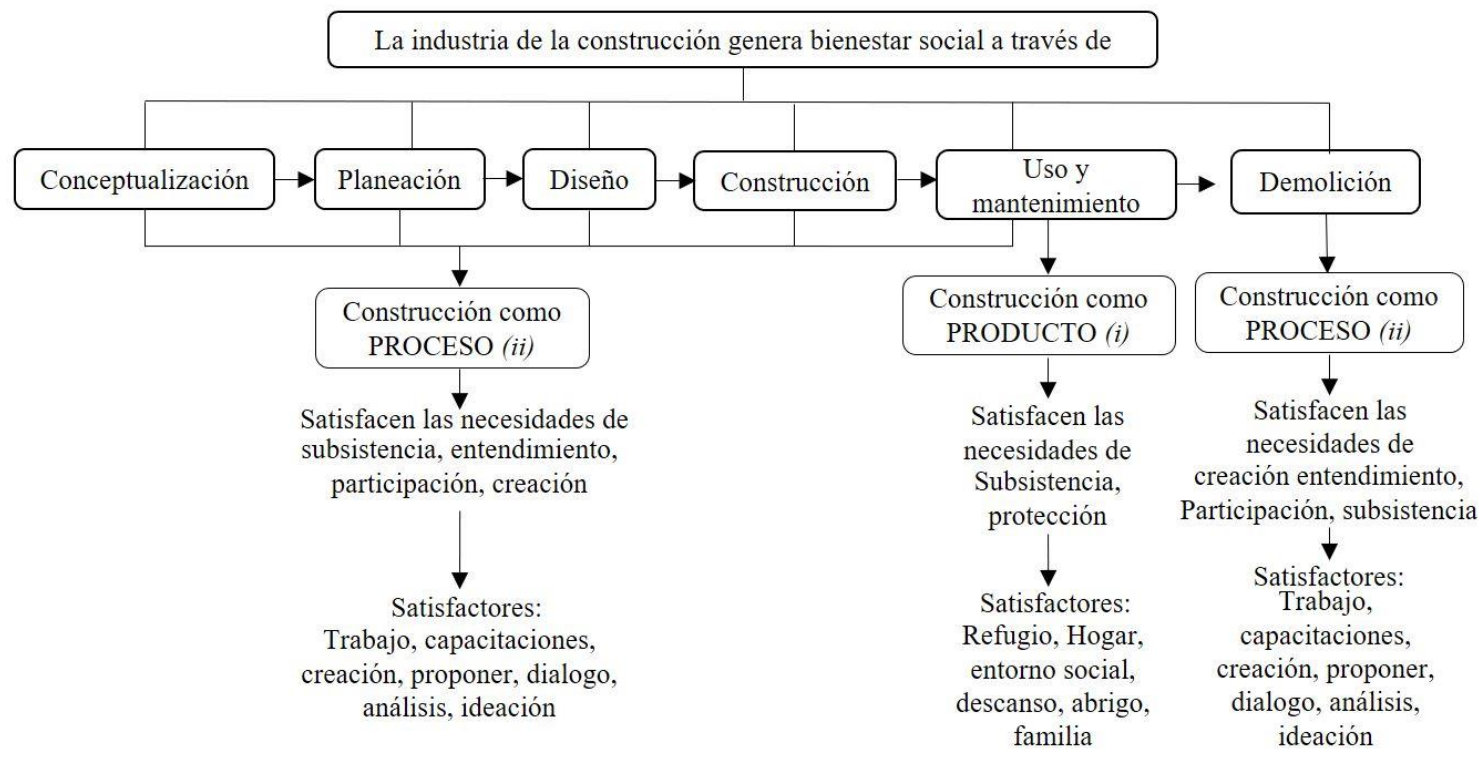

FUENTE: Elaboración propia.

Lean Construction es una filosofía asociada a los procesos de producción en construcción (KOSKELA et al., 2002) y ofrece la oportunidad de mejorar la construcción como proceso a través de la reducción de pérdidas, el aumento de la eficiencia, la agregación de valor para el cliente (KOSKELA, 1992) y la generación de bienestar para todos los involucrados durante el proceso (LIKER, 2004). Desde sus orígenes, Lean fue fundamentada en el pilar del respeto por las personas, bajo la primicia de "Primero construimos personas, luego construimos autos"(LIKER, 2004). Partiendo de la idea que todo sistema de producción debía centrarse en el bienestar de los trabajadores (DAHLGAARD; DAHLGAARD-PARK, 2006), posicionando al trabajador en el centro de todos los procesos que se llevaban a cabo, valorando su labor y potenciando sus capacidades (EMILIANI, 2008). En construcción, esta primicia significaría que, antes de generar bienestar a partir del producto fabricado, se debería generar bienestar a partir de su proceso de fabricación, de tal forma que todos los trabajadores cuenten con condiciones de bienestar adecuadas en su trabajo.

\subsection{Criterios de bienestar laboral abordados desde la Construcción Sostenible y Lean Construction}

Considerar criterios de bienestar laboral durante los procesos de construcción, brinda oportunidades para mejorar significativamente la calidad de vida de los trabajadores (SHAN et al., 2016), además de repercutir positivamente en el desempeño del proyecto (BRYSON; FORTH; STOKES, 2014).

Desde la Construcción Sostenible, los acercamientos más fuertes al bienestar laboral de los trabajadores de construcción se han presentado desde las áreas de la salud y seguridad ocupacional, para la disminución de accidentes y enfermedades laborales (CHANDRA, 2015; HINZE; GODFREY; SULLIVAN, 2013; MOSLY, 2016; RAJENDRAN; GAMBATESE, 2009). No obstante, hay autores que han hecho esfuerzos por recopilar indicadores de sostenibilidad social, con el propósito de evaluar aspectos de trabajo decente y bienestar laboral en obras de construcción (FERNÁNDEZ-SÁNCHEZ; RODRÍGUEZ-LÓPEZ, 2010; JOHNSEN; DREVLAND, 2016; KHODEIR; OTHMAN, 2016; MATEUS; BRAGANÇA, 2011; 
SIBRAGEC - ELAGEC 2019 - del 23 al 25 de Octubre - LONDRINA - PR

VASCONCELOS et al., 2015; VIEIRA; CACHADINHA, 2011). Igualmente, algunos sistemas de certificación de edificaciones sostenibles como LEED, BREEAM, GBI y BCA Green Mark, presentan créditos de sostenibilidad social que permiten evaluar el bienestar de los trabajadores durante la fase de construcción. En la Figura-4, se presentan los criterios de bienestar laboral abordados desde la construcción sostenible.

Figura-4. Criterios de bienestar laboral abordados desde la Construcción

\section{Sostenible}

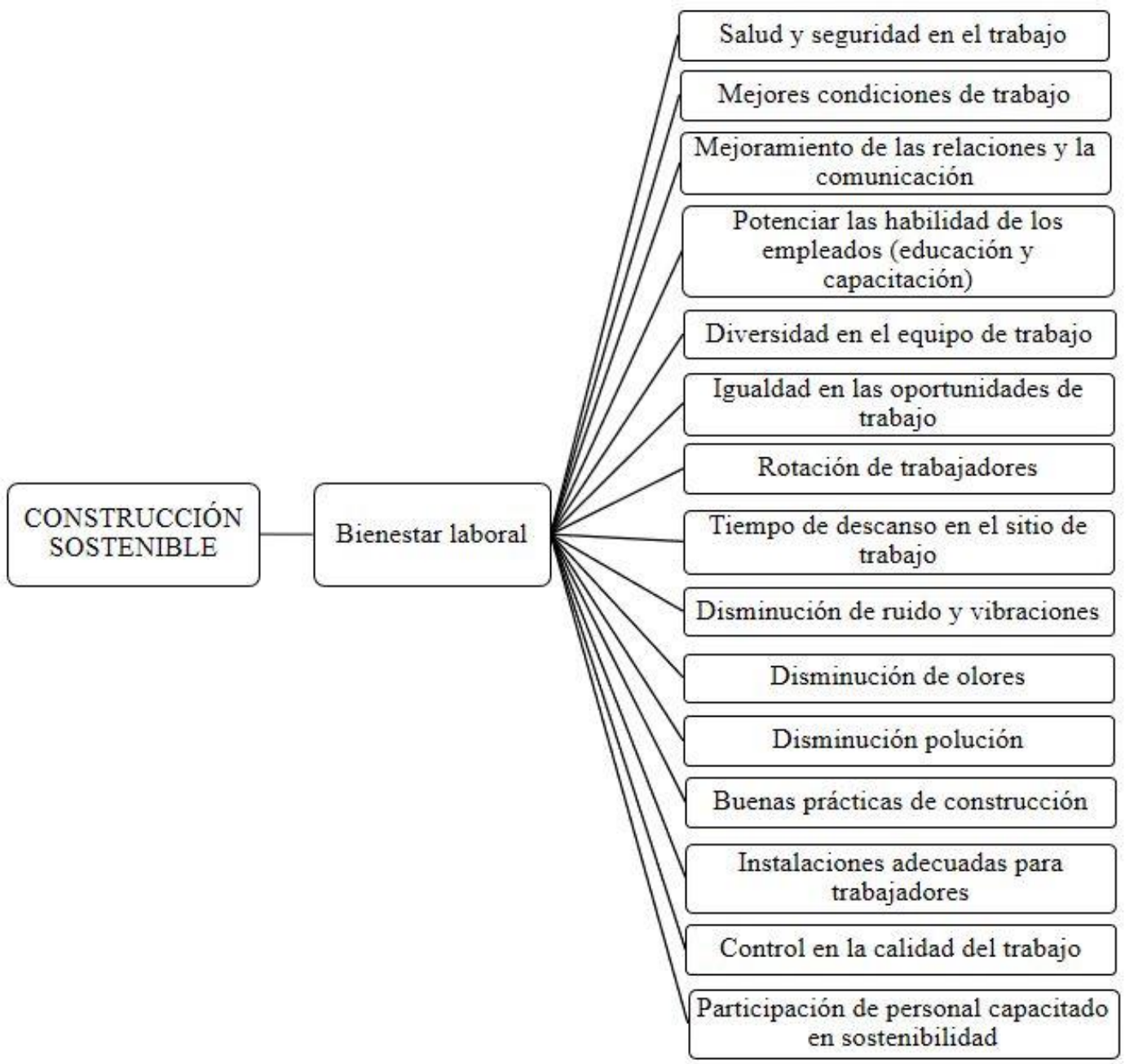

FUENTE: Elaboración propia.

En la filosofía Lean Construction, el bienestar laboral de los trabajadores de construccion tambien ha sido abordado desde la salud y la seguridad en el trabajo (MANOLACHE et al., 2012) (EMUZE; SMALLWOOD, 2013), el aumento de la percepción de seguridad (HOWELL; BALLARD; DEMIRKESEN, 2017) y la disminución del estrés (DANTAS FILHO et al., 2018), todos con el fin de aumentar la eficiencia en los procesos. Adicionalmente, se ha evidenciado que en los lugares de trabajo donde se empodera, motiva, respeta y se soporta al trabajador, se propicia a la innovación y a la creatividad, aumentando su desempeño (KENNEDY; BREWER, 2012). El pilar del respeto por las personas se fundamenta precisamente en esto, en el trabajo en equipo a través de la cooperación y la participación continua, la confianza mutua, el crecimiento personal y profesional, la motivación, el empoderamiento y la 
potenciación de capacidades y habilidades (EMILIANI, 2008)(COETZEE; VAN DYK; VAN DER MERWE, 2018). En la Figura-5, se pueden apreciar los criterios de bienestar laboral considerados por el pilar del respeto por las personas.

Figura-5. Criterios del pilar respeto por las personas, Lean-Construction.

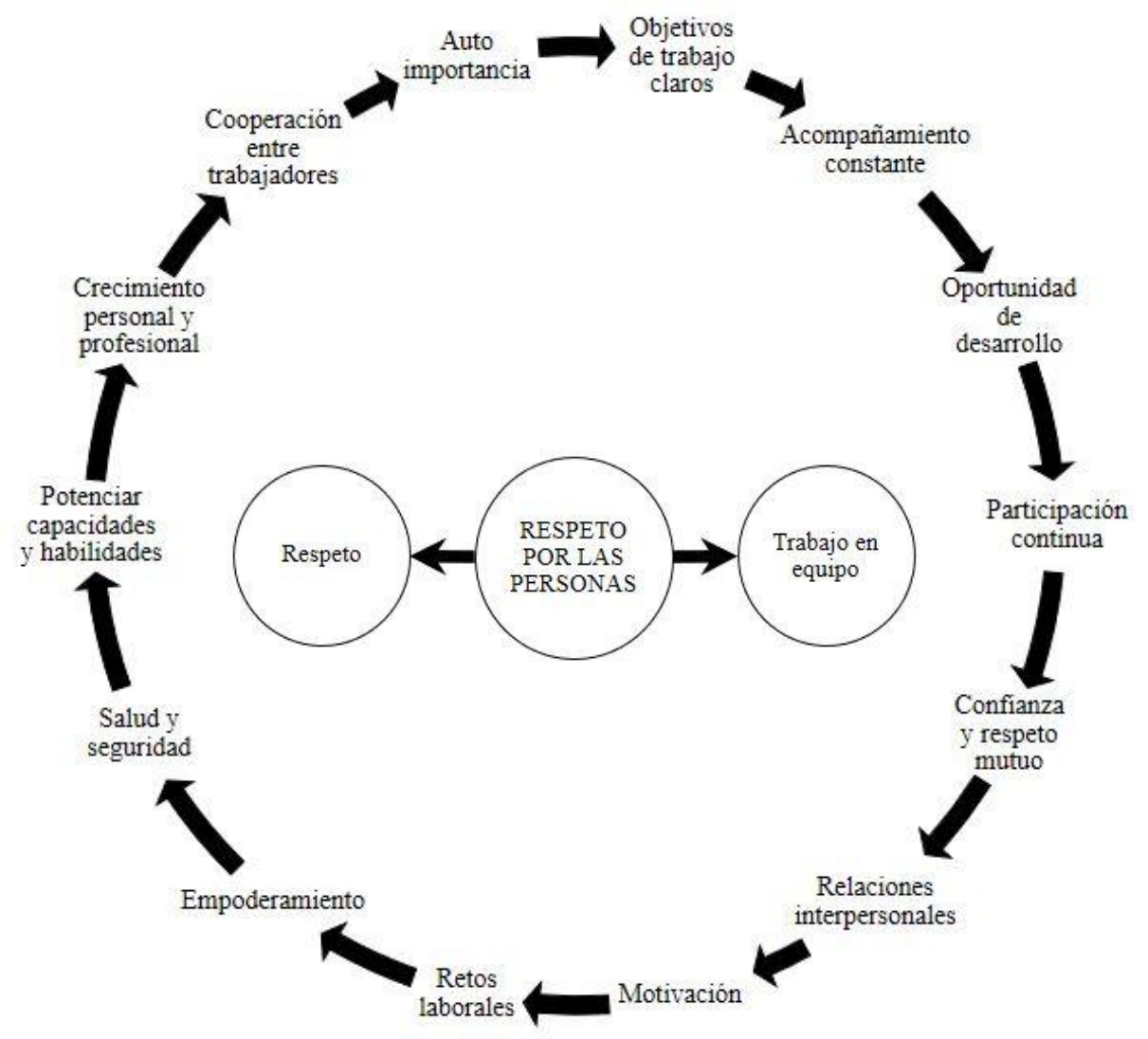

FUENTE: Elaboración propia.

\section{CONCLUSIONES Y CONSIDERACIONES FINALES}

Desde los campos de la psicología y la sociología, el bienestar laboral es un tema que ha sido ampliamente estudiado. No obstante, su estudio aún continúa siendo incipiente en construcción, especialmente en la búsqueda de criterios que permitan el mejoramiento de la calidad de vida laboral de los trabajadores de construcción. Las filosofías Lean y Construcción Sostenible, desde sus fundamentos conceptuales, están estrechamente relacionadas con el bienestar de las personas y por tal razón, presentan la oportunidad para abordar el bienestar laboral del trabajador de construcción de una manera más completa. Desde la Construcción Sostenible, se han generado indicadores de carácter social para la evaluación del bienestar durante los procesos, no obstante, aún se carece de los medios necesarios que permitan alcanzar satisfactoriamente estos criterios de bienestar. Lean, al ser una filosofía enfocada directamente en los procesos, cuenta con herramientas, estrategias y buenas prácticas, es decir, los medios necesarios para la generación de bienestar en obras de construcción. El presente estudio sirve como punto de referencia para futuras investigaciones enfocadas en el estudio del bienestar laboral en los procesos de construcción. 
SIBRAGEC - ELAGEC 2019 - del 23 al 25 de Octubre - LONDRINA - PR

\section{REFERENCIAS}

ABREY, M.; SMALLWOOD, J. J. The effects of unsatisfactory working conditions on productivity in the construction industry. Procedia Engineering, v. 85, p. 3-9, 2014.

BAJJOU, M. S. et al. The practical relationships between lean construction tools and sustainable development: A literature review. Journal of Engineering Science and Technology Review, v. 10, n. 4, p. 170-177, 2017.

BELL, N.; POWELL, C.; SYKES, P. Securing the Well-Being and Engagement of Construction Workers: an Initial Appraisal of the Evidence. 31st Annual ARCOM Conference, $n$. September, p. 489-498, 2015.

BODNER, T. et al. Safety, health, and well-being of municipal utility and construction workers. Journal of Occupational and Environmental Medicine, v. 56, n. 7, p. 771-778, 2014.

BRADLEY, L. et al. Improving Employees' Work-Life Balance in the Construction Industry: Project Alliance Case Study. Journal of Construction Engineering and Management, v. 133, n. 10, p. 807-815, 2007.

BRAMBLE, B. A New Defense of Hedonism about Well-Being. Ergo, v. 3, n. 4, p. 85-112, 2016.

BRUNDTLAND, G. H. Our Common Future: Report of the World Commission on Environment and DevelopmentUnited Nations Commission. [s.l: s.n.].

BRYSON, A.; FORTH, J.; STOKES, L. Does Worker Wellbeing Affect Workplace Performance? n. 9096, 2014.

CHANDRA, H. P. Initial investigation for potential motivators to achieve sustainable construction safety and health. Procedia Engineering, v. 125, p. 103-108, 2015.

CHOI, S. D. A study of trade-specific occupational ergonomics considerations in the U.S. construction industry. Work, v. 42, n. 2, p. 215-222, 2012.

COETZEE, R.; VAN DYK, L.; VAN DER MERWE, K. R. Towards addressing respect for people during lean implementation. International Journal of Lean Six Sigma, 2018.

COLE, D. A. et al. A longitudinal study of negative affect and self-perceived competence in young adolescents. Journal of Personality and Social Psychology, v. 77, n. 4, p. 851, 1999.

COSTA, P. T.; MCCRAE, R. R. Influence of extraversion and neuroticism on subjective wellbeing: Happy and unhappy people. Journal of Personality and Social Psychology, v. 38, n. 4, p. 668-678, 1980.

DAHLGAARD, J. J.; DAHLGAARD-PARK, S. M. Lean production, six sigma quality, TQM and company culture. [s.l: s.n.]. v. 18

DAMAJ, O. et al. Implementing Ergonomics in Construction To Improve Work Performance. International Group for Lean Construction, p. 53-62, 2016.

DANTAS FILHO, J. B. P. et al. Respect for people's well-being: meditation for construction workers. Proc. 26th Annual Conference of the International. Group for Lean Construction. Anais...2018

DE CARVALHO, A. C. V.; GRANJA, A. D.; DA SILVA, V. G. A systematic literature review on integrative lean and sustainability synergies over a building's lifecycle. Sustainability (Switzerland), v. 9, n. 7, 2017.

DĖJUS, T.; ANTUCHEVIČIENĖ, J. Assessment of health and safety solutions at a construction site. Journal of Civil Engineering and Management, v. 19, n. 5, p. 728-737, 2013.

DIENER, E. Subjective well-being: The science of happiness and a proposal for a national index. American psychologist, v. 55, n. 1, 2000. 
DIENER, E.; RYAN, K. Subjective well-being : a general overview. South African Journal of Psychology, v. 39, n. 4, p. 391-406, 2009.

DIENER, E.; SUH, E. Measuring quality of life: Economic, social, and subjective indicators. Social indicators research, v. 40, n. 1-2, p. 189-216, 1997.

DODGE, R. et al. The challenge of defining wellbeing. Journal of Wellbeing, v. 2, n. 3, p. 222-235, 2012.

EAVES, S.; GYI, D. E.; GIBB, A. G. F. Building healthy construction workers: Their views on health, wellbeing and better workplace design. Applied Ergonomics, v. 54, p. 10-18, 2016.

EMILIANI, M. L. The equally important "respect for people" principle. n. April, p. 1-8, 2008.

EMUZE, F.; SMALLWOOD, J. The integration of health and safety (H\&S), lean and sustainability in construction: A literature review. IGLC-21. Anais...2013

FERNÁNDEZ-SÁNCHEZ, G.; RODRÍGUEZ-LÓPEZ, F. A methodology to identify sustainability indicators in construction project management-Application to infrastructure projects in Spain. Ecological Indicators, v. 10, n. 6, p. 1193-1201, nov. 2010.

GATTI, U. C. et al. An exploratory study of the relationship between construction workforce physical strain and task level productivity. Construction Management and Economics, v. 32, n. 6, p. 548-564, 2014.

HINZE, J.; GODFREY, R.; SULLIVAN, J. Integration of Construction Worker Safety and Health in Assessment of Sustainable Construction. Journal of Construction Engineering and Management, v. 139, n. 6, p. 594-600, 2013.

HOWELL, G.; BALLARD, G.; DEMIRKESEN, S. Why lean projects are safer. Proceedings of the 25th Annual Conference of the International Group for Lean Construction. Anais...2017

ILO. Decent work. Disponível em: <https://www.ilo.org/global/topics/decent-work/lang-en/index.htm>. Acesso em: 13 ago. 2018.

JAAFAR, M. H. et al. Occupational safety and health management in the construction industry: a review. International Journal of Occupational Safety and Ergonomics, v. 0, n. 0, p. 1-14, 2017.

JOHNSEN, C. A.; DREVLAND, F. Lean and Sustainability: Three Pillar Thinking in the Production Process. Proceedings of the 24th Annual Conference of the International Group for Lean Construction (IGLC). Anais...2016

JOSEP M, B. et al. Cuestionario de Bienestar Laboral General: Estructura y Propiedades Psicométricas. Revista de Psicología del Trabajo y de las Organizaciones, v. 26, n. 2, p. 157170, 2010.

KENNEDY, F.; BREWER, P. Motivating employee performance in lean environments: respect, empower, support. In: Lean accounting: best practices for sustainable integration. [s.l: s.n.]. p. 93-118KENNEDY, F.; BREWER, P. Motivating employee.

KHODEIR, L. M.; OTHMAN, R. Examining the interaction between lean and sustainability principles in the management process of AEC industry. Ain Shams Engineering Journal, 2016.

KOSKELA, L. Application of the new production philosophy to construction. Center for Integrated Facility Engineering, p. 1-81, 1992.

KOSKELA, L. et al. The foundations of lean construction. Design and Construction: Building in Value, n. December 2015, p. 211-226, 2002.

LANGDON, R. R.; SAWANG, S. Construction Workers' Well-Being: What Leads to Depression, Anxiety, and Stress? Journal of Construction Engineering and Management, v. 144, n. 2, p. 04017100, 2017. 
SIBRAGEC - ELAGEC 2019 - del 23 al 25 de Octubre - LONDRINA - PR

LIKER, J. K. The Toyota Way: 14 Management Principles from the World's Greatest Manufacturer. New York City: [s.n.]. v. 1

LIM, S. et al. Analyzing psychological conditions of field-workers in the construction industry. International Journal of Occupational and Environmental Health, v. 23, n. 4, p. 261-281, 2017.

LINGARD, H.; TURNER, M. Promoting construction workers' health: a multi-level system perspective. Construction Management and Economics, v. 35, n. 5, p. 239-253, 2017.

LORENTE, L. et al. How personal resources predict work engagement and self-rated performance among construction workers: A social cognitive perspective. International Journal of Psychology, v. 49, n. 3, p. 200-207, 2014.

MANOLACHE, C. T. et al. Lean construction and occupational health and safety risks in construction project management : the case of ironworkers : a short literature review. n. Lc, 2012.

MATEUS, R.; BRAGANÇA, L. Sustainability assessment and rating of buildings: Developing the methodology SBToolPT-H. Building and Environment, v. 46, n. 10, p. 1962-1971, 2011.

MAX-NEEF, M. A.; ELIZALDE, A.; HOPENHAYN, M. Desarrollo a escala humana : conceptos, aplicaciones y algunas reflexiones. [s.l.] Icaria, 1998.

MEADOWS, D. H. et al. The Limits to Growth: A Report to The Club of Rome (1972). [s.l: s.n.]. Disponível em: <http://www.ask-force.org/web/Global-Warming/Meadows-Limits-toGrowth-Short-1972.pdf>. Acesso em: 9 abr. 2019.

MOHSENI, P. H. et al. Assessment of the living and workplace health and safety conditions of site-resident construction workers in Tehran, Iran. International Journal of Occupational Safety and Ergonomics, v. 21, n. 4, p. 568-573, 2015.

MOSLY, I. The Integration of Worker Safety and Health into Sustainable Construction Practices: A Review. Advances in Safety Management and Human Factors, p. 223-230, 2016.

MOSTERT, K.; PEETERS, M.; ROST, I. Work-home interference and the relationship with job characteristics and well-being: A South African study among employees in the construction industry. Stress and Health, v. 27, n. 3, 2011.

NIKOLIN, B. et al. A Call for New Research in the Lean Construction Community: Alternative Work Schedules. 23rd Annual Conference of the International Group for Lean Construction, n. July, p. 435-443, 2015.

OGUNBIYI, O.; OLADAPO, A.; GOULDING, J. An empirical study of the impact of lean construction techniques on sustainable construction in the UK. Construction Innovation, v. 14, n. 1, p. 88-107, 2014.

ONU. Rio+20. Conferencia de las Naciones Unidas sobre el desarrollo sostenible. Rio de Janeiro: [s.n.]. Disponível em:

<https://www.un.org/es/sustainablefuture/pdf/spanish_riomas20.pdf>. Acesso em: 9 abr. 2019.

POLLARD, E. L.; LEE, P. D. Child well-being: a systematic review of the literature. Social Indicators Research, v. 61, n. 1, p. 59-78, 2003.

RAJENDRAN, S.; GAMBATESE, J. A. Development and Initial Validation of Sustainable Construction Safety and Health Rating System. Journal of Construction Engineering and Management, v. 135, n. 10, p. 1067-1075, 2009.

ROZENFELD, O. et al. Construction Job Safety Analysis. Safety Science, v. 48, n. 4, p. 491498, 2010. 
RYAN, R. M.; DECI, E. L. On happiness and human potentials: A review of research on hedonic and eudaimonic well-being. Annual review of psychology, v. 52, n. 1, p. 141-166, 2001.

RYFF, C. D. Happiness Is Everything, or Is It? Explorations on the Meaning of Psychological Well-Being. Journal of Personality and Social Psychology, v. 57, n. 6, p. 1069-1081, 1989.

RYFF, C. D. Psychological Wellbeing in Adulthood. Current Directions in Psychological Science, v. 4, n. 4, p. 99-104, 1995.

RYFF, C. D.; SINGER, B. H. Know thyself and become what you are: A eudaimonic approach to psychological well-being. Journal of Happiness Studies, v. 9, n. 1, p. 13-39, 2008.

SANG, K. J.; ISON, S. G.; DAINTY, A. R. The job satisfaction of UK architects and relationships with work-life balance and turnover intentions. Engineering, Construction and Architectural Management, v. 16, n. 3, p. 288-300, 2009.

SEGURADO TORRES, A.; AGULLÓ, E. Calidad de vida laboral : hacia un enfoque integrador desde la Psicología Social. Psicothema, v. 14, p. 828-836, 2002.

SELIGMAN, M. Flourish: A new understanding of happiness, well-being-and how to achieve them. Journal of Positive Psychology, v. 7, n. 2, p. 159-161, 2012.

SHAN, Y. et al. Investigating the Latent Factors of Quality of Work-Life Affecting Construction Craft Worker Job Satisfaction. Journal of Construction Engineering and Management, v. 143, n. 5, p. 04016134, 2016.

TURNER, M.; MARIANI, A. Managing the work-family interface: experience of construction project managers. International Journal of Managing Projects in Business, v. 9, n. 2, p. $243-$ 258, 2016.

ULUBEYLI, S.; KAZAZ, A.; ER, B. Health and safety perception of workers in turkey: A survey of construction sites. International Journal of Occupational Safety and Ergonomics, v. 20, n. 2, p. 323-338, 2014.

VASCONCELOS, I. A. DE et al. Guidelines for Practice and Evaluation of Sustainable Construction Sites : a Lean, Green and Wellbeing Integrated Approach. Proceedings of the 23th Annual Conference of the International Group for Lean Construction (IGLC). Anais...2015

VIEIRA, A. R.; CACHADINHA, N. Lean construction and sustainability - complementary paradigms? a case study. Proceeding of 19th Annual Conference of IGLC, p. 611-621, 2011.

WATTERSON, A. Global construction health and safety - What works, what does not, and why? International Journal of Occupational and Environmental Health, v. 13, n. 1, p. 1-4, 2007.

WEINHEIMER, N.; SCHMALZ, S.; MÜLLER, D. Green Building and Lean Management: Synergies and Conflicts. Proceedings of the 25th Annual Conference of the International Group for Lean Construction (IGLC). Anais...2017

ZHAO, X. D. The Occupational Health and Safety Management of Workers in Building Construction Site. Applied Mechanics and Materials, v. 501-504, p. 2695-2699, 2014. 